\title{
Albert Camus in Uzbekistan
}

\author{
A. Kasimov
}

Associated Professor, Fergana State University, Uzbekistan

\begin{abstract}
The article is devoted to the issue of Camus `s influence on Uzbek writers and translation of his works. It also considers the process of including information about Camus to the High Educational Institutions curriculum.
\end{abstract}

Keywords- Camus, The Plage, The Stranger, The Rebel, Absurd, existentialism, philosophical essay, ideological-aesthetic attitudes.

From1990s, greater emphasis was placed on analysis of personal "I" in Uzbek prose and poetry. In particular, the character in prose has not been considered as social phenomenon connected with society and politics but also to study personality with its original world has become primary criterion. Literary critic A. Ulugov named this "Western conditional method" restating its influence on the renewal of Uzbek literature. Realistic images were harmonized with unconventionality in the numerous works of M.Muhammaddost, H. Dostmuhammad, T. Murod, NazarEshonqul and ShodiqulHamro.

Creative heritage of Alert Camus is considered as an important page of literature and philosophy of XX century. Author`s works which has original conclusions and discusses eternal problems of a man were well known in his life time. There was big interest to his philosophical views and creative work between educated people and other authors. That's why it is very important and necessary to talk about his influence to the second part of XX century literary process.

Camus had some restrictions many years in ex-Soviet Union. At this period he was known as the author of novel "la Peste" which has description of Fascist symbolic image and that he was a member of French Communist Party and became associated with the French anarchist but there were no discussions about his ideas according to existentialism and absurdism and also his philosophical essays. Information about the author was given from this particular point of view even at the curriculum of High Educational Institutions.

Data about Camus`s literary career came to Uzbekistan rather than that. To tell the truth, all information concerning the author and translation of his works, which were published in Russia, were acceptable for Uzbek people. Unfortunately, there was no information in Uzbek language. Although information about the author was included into, the High Educational Institutions curriculum but there had been no data about Camus in course book on the subject of the history of World literature for students of philology faculties for a long time.

In the last $80^{\text {th, }}$ Camus became more popular in Uzbekistan. As a result, true information about the author, translation of his works, some extracts from his works in Uzbek became available for Uzbek readers [1].

His world famous two works play "The Stranger" and "The Plague" novel were translated into Uzbek by Ahmad Azam in 1995 [2]. This date is an important event between French-Uzbek partnership.

Extract from A. Camus`s "The Rebel" was published in the first volume of the journal "Jahonadabiyoti" in 1997. It was "Rebellion and Art", which was translatedfrom Russian version by NazarEshonqulandY. N. Stefanov [3] made Russian translation. It consisted from philosophical essays as "Novel and rebellion", "Rebellion and style" and "Rebellion and Revolution" [4].

Furthermore Camus`s Nobel Prize speech under the title "Being writers is an honor" was published in the journal "Jahonadabiyoti" and some extracts from his "Notebooks" were published at the newspaper "Uzbekistan adabiyotivasa 'nati” [5].।

Translation activities of Camus creative heritage have been fruitful recently. It have great opportunity to be acquainted with the author`s thoughts, style, philosophical outlook and his ideological- aesthetic attitudes. Besides it was enough bases to talk about Camus`s influence to the literary process of Uzbekistan. There have been appeared some comparative researches and some articles due to Camus's attitudes to the Existentialism and his philosophical thoughts. This fact proves that Camus`s works have been read and studied in Uzbekistan not in 
Russian language as it was done in the late $80^{\text {th }}$ of $\mathrm{XX}$ century but in Uzbek language.

Because of enormous interest there have been donemany research works. We can observe appraisal to author`s majority works and creative aspects of his personality in some articles concerning Camus.

Moreover literary critic U. Normatov in his notes about Modern literary process shared with his ideas according to Camus`s creative work. He stressed that Camus's "The Stanger" was the object of studying personality of the author where Camus made a significant contribution to a viewpoint of the Absurd [6]. M. Sheraliyeva, Holbekov, Sh. Tuychiyeva and M. Quchqorova have compared certain characters from Uzbek literature. Sheraliyeva, Holbekov, Sh. Tuychiyeva and M. Quchqorova have compared certain characters from Uzbek literature with Camus`s hero`s personality and they have given their conclusion according to this issues. If Sh. Tuychiyeva in her article compares styles which was used by Camus in the "The Stanger" and Chulpon's novel "KechavaKunduz" [7]. M. Quchqorova gives her ideas according to the peculiarities Camus's and Chulpon's essays. She also compares symbols which both author used in their works [8].

In addition debates. Discussions and articles which have been published recently in certain journals and newspapers such as "Sharqyulduzi, "Jahonadabyoty", "UzbekistonadabyotivaSa 'nati" focused on modern literary process and absurdism. They also analyze Camus and his influence to the Modern literature.

Studying Camus`s literary career in High Educational Institutions have been established [9]. Curriculum design in concentrated on including date base on literature of French existentialism especially Sartre and A. Camus`s life and literary career.

Last but courageous step has been done to study Camus in Uzbekistan by including theme about the author to the secondary school curriculum [11].

There are some passages from "The Stranger" in the course book. It gives schoolchildren to understand Meursault, the absurdist hero of the strange, who has killed a man and is scheduled to be executed.

The story was estimated as one of the Camus` the best work and prominent philosophical myths. Some opinions were given due to the ideological and aesthetic value of story. All events in court process confirm Meursault's stranger`s position toward society and environment. Of course, murder must be punished. You feel injustice when he is scheduled to be executed (page223). These ideas make reader to reflect deep.

To sum up we can note that Camus`s style, thought, absurdizm, description of personal "I" of character have a great influence on some Uzbek writers especially $\mathrm{N}$. Eshonqul, T.Rustam, H. Dustmuhammad. One angle, which is discontent with aged form and conviction, assembled the representatives of a new generation such as NazarEshonqul, ShodiqulHamro, ShoyimBotayev. Sh. Normatova in her research pinpointed that theses authors described a human being as a special spiritual persona. In this regard, numerous highly rated literary works of NazarEshonqul are noteworthy. Symbols bear a special significance in his oeuvre. The author shows high preference for exaggeration in depicting several aspects of social life.

N. Eshonqul's story "Muolaja" (Treatment) published in 1989 can be cited as an allegory against Soviet Union.The above story illustrates ill-fated society of underprivileged self-deprived naive people. The story is based upon the conversation between a young correspondent and an unknown professor.

The story roots its care essence in the rush less Stalinist system, which humiliated and restricted the emergence of patriotic, forward-looking people. The literary piece widely deals with the mistreatment of victims desperate for free civil society.

Another literary piece of NazarEshonqul "Tobut" (Coffin) bears a close resemblance to Camus' novel "The Plague" in its issues and narration. Investigator of Modern Uzbek storytelling S. Sattorova cited evidence in favor of this statement. The story is narrated by a young architect who joined an expedition team that was heading to a remote residence plagued with death for some unknown reason. The mysterious plot in the sequence of events reminds plague scenes in Oran city.

Literary criticism believes that the novels, which appeared after World War II, contain figurative image of Fascism. DilmurodQuronov while addressing the poetry of Chulponclaims, "The real author lives within the horizons of past, present and future, he knows no boundaries". In this sense, Camus' novel "The Plague" proves not only figurative image of fascism but unmanageable mysterious force that comes into being to turn people upside down. Calamity of this kind may occur in every society where nonchalance and indifference among individuals are vastly prevalent.

NazarEshonqul makes optimal use of figurative sense of lexical base in his writings. The problem, which seemed paradoxical,is revealed in the end: which is the 
construction pattern of the village in the shape of coffin. This, in turn, denotes the prediction about the decline of the city. Literally, coffin signifies unavoidable death.

After thorough examination, it can be inferred that the author attempts to allude Soviet regime as a coffin, and a fetid odor surrounding the city as an ideology of that backward-looking, conservative society.

Literary criticism used in the novel "Coffin" can be seen in several works created later in 1990s. The characters in theses novels are depicted through unreal or unnatural images. Behind theses absurd images lies the illustration of Soviet communism and moral, spiritual world of its selfdeprived victims.

To sum up we can say that philosophical examination upon real-life circumstances was given top priority. Symbols became essential component of prose copmbining the elements of Eastern classicism as well as Western modernism. Symbols were primarily used to form literary image and principles of ruthless Soviet Union. Studying the influence of Camus oeuvre is considered fundamental part of establishing mutual relations between Uzbek and French literature. Accordingly, interexchange of the two aforementioned literary studies will remain as a set of principal issues.

Correlations between those two literatures including their typical similarities serve as an indispensable part of intercultural communication.

\section{REFERENCES}

[1] Uzliknianglash- isyon. Falsafiyesselar// Yoshlik 1989. №1. P.57-62.

[2] Kamyu A. Begona: qissava roman.- T.:Yozuvchi, 1995. P.320.

[3] Kamyu A. Buntuyushiychelovek. -M.: Izd-vopolitich. Literaturi. 1990. P. 316-336.

[4] Kamyu A. Isyonvasanat ("Isyonkorodam" kitobida n). N.Eshonqultarj. // Jahonadabyoti. 1997.№1. P. 183-197.

[5] Kamyu A.

Men hechnarsadankuzyummaslikniafzalbilaman. (A. Kamyu "Kundaliklar"idan)/ UzAS. 14yanvar, 2005.

[6] Normaton U. Nazariyavaadabyiybadiiyjarayon // Jahonadabyoty. 2000 №3. P. 159.

[7] Tuychiyeva Sh. ChulponvaKamyu // Jahonadabyoti. 2001. №6. P. 146-152.

[8] Quchqorova M. ChulponvaKamyuesselaridaramz // Tafakkur. 2003 №1.p. 121-123.

[9] Oliy uquv yurtlarining filologiya yunalishi uchun dastur. T.: Universitet, 1997.

[10] Karimov N., Mirzayev va boshq. Albert Kamyuninghayotivaijodiyuli. "Begona" (qissasidanparcha). "Begona" qissasitug risida//Adabiyot. 9-sinf uchundarslik, - T.: Manaviyat, 2002.p. 